\title{
HUBUNGAN SANITASI DASAR RUMAH DENGAN KEJADIAN INFEKSI SALURAN PERNAPASAN AKUT (ISPA) DI WILAYAH KERJA PUSKESMAS DUKUN KECAMATAN DUKUN KABUPATEN GRESIK TAHUN 2019
}

\author{
Rangga Fajar Abdillah ${ }^{1}$ dan Isti'anah ${ }^{2}$ \\ ${ }^{1}$ Dosen Program Studi Kesehatan Lingkungan Universitas Islam Lamongan \\ ${ }^{2}$ Mahasiswa Program Studi Kesehatan Lingkungan Universitas Islam Lamongan
}

\section{rangga.fajar1989@gmail.com, aisti262@gmail.com}

\begin{abstract}
ABSTRAK
Infeksi Saluran Pernafasan Akut (ISPA), merupakan salah satu penyakit yang sering menyerang anak-anak bahkan orang yang dewasa salah satu faktor yang menyebabkan ISPA yaitu pola kebiasaan masyarakat di wilayah kerja UPT. Puskesmas Dukun yaitu kurang menjaga dan memahami tentang pola hidup yang sehat di sekitar rumah yang meliputi ventilasi rumah, pencahayaan alami rumah, kelembapan rumah, lantai rumah, dinding rumah, dan atap rumah. Dari hasil inspeksi 11 desa 110 rumah dari 14 desa 140 rumah di wilayah kerja Puskesmas Dukun rumah sehat yang memenuhi persyaratan sesuai dengan pedoman teknis penilaian rumah sehat tahun 2012 dengan nilai 1068-1280 dan rumah yang tidak sehat dengan nilai $\leq 1068$. Sehingga rumah yang memenuhi persyaratan berjumlah 47 rumah, sedangan yang tidak memenuhi persyaratan berjumlah 93 rumah. Jumlah data ISPA Tahun 2016, kasus tiap tahun mencapai peningkatan 1545 kasus pada akhir tahun 2019 ISPA mencapai 7624 kasus.Berdasarkan penelitian diatas bahwa ada hubungan antara sanitasi dasar rumah dengan kejadian ISPA di wilayak kerja UPT. Puskesmas Dukun pada tahun 2019 dipengaruhi oleh sanitasi dasar rumah seperti; ventilasi yang kurang baik, pencahayaan kurang, jendela kamar tidur dan ruang keluarga yang jarang dibuka, kondisi lantai yang berdebu, langit-langit yang mudah menimbulkan debu dan sulit untuk dibersihkah, dinding rumah yang lembab dan faktor perilaku penghuni hal tersebut dapat mempengaruhi karena jika ventilasi maupun jendela tidak dibuka maka sirkulasi udara tidak dapat berjalan dengan baik dan akan mengakibatkan kelembapan yang menimbbulkan patogen yang menyebabkan ISPA.
\end{abstract}

Kata kunci : Sanitasi dasar rumah, ISPA, Puskesmas 
PENDAHULUAN

Menurut Mariane (2003) sanitasi merupakan usaha pengawasan terhadap faktor-faktor lingkungan fisik manusia yang mempengaruhi atau mungkin dipengaruhi, sehingga dapat merugikan perkembangan fisik, kesehatan dan kelangsungan hidup.

Rumah sehat merupakan salah satu sarana untuk mencapai derajat kesehatan yang optimum. Untuk memperoleh rumah yang sehat ditentukan oleh tersedianya sarana sanitasi perumahan. Sanitasi rumah merupakan usaha kesehatan masyarakat yang menitikberatkan pada pengawasan terhadap struktur fisik dimana orang menggunakannya untuk tempat tinggal berlindung yang mempengaruhi derajat kesehatan manusia. Rumah juga merupakan salah satu bangunan tempat tinggal yang harus memenuhi kriteria kenyamanan, keamanan dan kesehatan guna mendukung penghuninya agar dapat bekerja dengan produktif (Arifin, 2009).

Penyakit Infeksi Saluran Pernapasan Akut (ISPA) mencakup penyakit saluran napas bagian atas dan bagian bawah. ISPA mengakibatkan kematian pada anak dalam jumlah kecil, tetapi dapat menyebabkan kecacatan misalnya, otitis media yang merupakan penyebab ketulian.

Sesuai data dari Puskesmas Dukun Kabupaten Gresik, kasus ISPA pada pada tahun 2016 mencapai 6079 kasus, jumlah konseling 3001 dengan prevalensi kasus 49\% pada tahun 2017 mencapai 7142 kasus, jumlah konseling 3580 dengan prevalensi kasus 52\% dan pada tahun 2019 sebanyak 7624 kasus, jumlah konseling 3921 dengan prevalensi kasus 60\%. Data penyakit ISPA berdasarkan usia $<5$ tahun, hal ini menunjukkan bahwa angka kejadian ISPA pada balita di wilayah kerja Puskesmas Marisa semakin bertambah (Puskesmas Dukun, 2019).

Berdasarkan data penderita ISPA dari tahun 2016 sampai tahun 2019 maka dapat disimpulkan bahwa ada hubungan sanitasi yang buruk terhadap kualitas kesehatan warga Kecamatan Dukun khususnya area wilayah kerja puskesmas. Oleh karena itu tujuan dari Praktek Kerja Lapangan adalah untuk mengetahui hubungan sanitasi dasar rumah dengan kejadian ISPA.

\section{PEALAKSANAAN PENELITIAN}

Penelitian ini dilaksanakan pada 03 Januari 2019 di UPT. Puskesmas Dukun Kecamatan Dukun Kabupaten Gresik.

\section{METODE PENELITIAN}

Metode penelitian yang digunakan adalah wawancara dan observasi. Wawancara dilakukan oleh perawat dan kader kesehatan lingkungan dengan menggunakan panduan form penilaian rumah sehat. Sementara observasi yang dilakukan menggunakan instrumen yang 
dibuat berdasarkan rujukan teori terkait sanitasi kesehatan di tempat-tempat umum dan sesuai pedoman teknis penilaian rumah sehat tahun 2012. Berdasarkan hasil penelitian terhadap 3 komponen aspek penilaian yakni komponen rumah, komponen sanitasi dan komponen perilaku penghuni. Rumah yang memenuhi syarat yakni berada pada skor 1068-1280 dan yang tidak memenuhi syarat berada pada skor $\leq 1068$ sedangkan pada jumlah penderita ISPA dihasilkan dari data pasien di klinik sanitasi UPT. Puskesmas Dukun.

\section{HASIL DAN PEMBAHASAN}

\section{A. HASIL}

Berdasarkan hasil penelitian, implementasi program sanitasi dasar rumah sebagian belum mencapai target, tetapi dalam implementasi masih ditemukan masalah dalam pensurvean diatanranya kurang pahamnya kader kesehatan lingkungan dalam memberi penilaian karena didukung dengan keahlian yang kurang dalam bidang sanitasi, sehingga menyebabkan ketidakpuasan dengan hasil tersebut. Untuk mengimplementasikan kebijakan tentang sanitasi dasar rumah maka UPT Puskesmas Dukun melakukan tugas sesuai dengan keahliannya, memberikan sosialisasi tentang pola hidup sehat seperti program PHBS, inspeksi rumah di setiap desa. Berikut adalah diagram pola hubungan antara sanitasi dasar rumah dengan kejadian ISPA di wilayah kerja Puskesmas Dukun tahun 2019;

1. Pola hubungan antara jumlah permasalahan langit-langit dengan kejadian ISPA

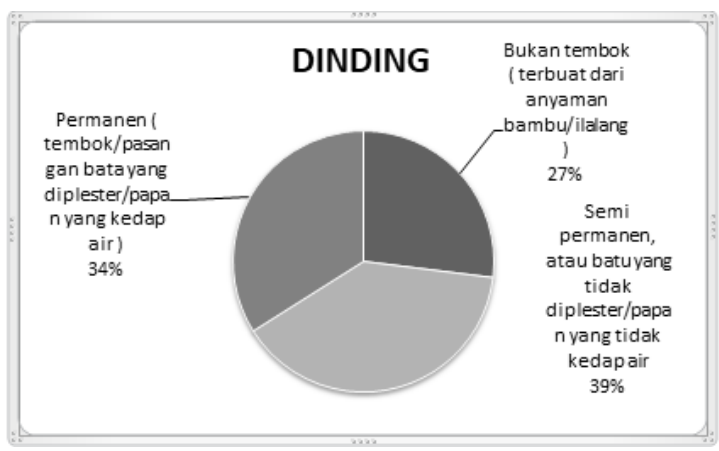

Gambar 1.Pola hubungan antara jumlah permasalahan langit-langit dengan kejadian ISPA

Berdasarkan hasil inspeksi sanitasi rumah sehat tahun 2019 menunjukan ada hubungan yang bermakna langit-langit dengan kejadian ISPA di wilayah kerja Puskesmas Dukun bahwasanya sebagian rumah responden memiliki atap dari genteng, plafon dan hal ini dapat menyebabkan masuknya debu kedalam rumah, selain itu sebagian atap rumah juga ada yang bocor, dan dapat mempengaruhi terjadinya kejadian penyakit ISPA, serta dapat memperburuk kondisi tempat tinggal responden.

2. Pola hubungan antara jumlah permasalahan dinding dengan kejadian ISPA 


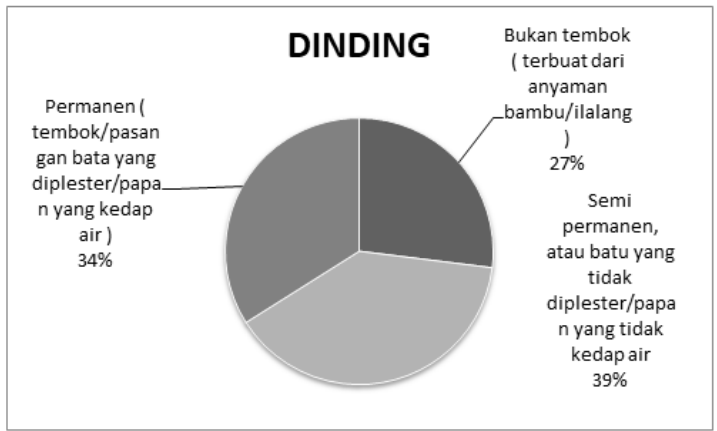

Gambar 2. Pola hubungan antara jumlah permasalahan dinding dengan kejadian ISPA

Berdasarkan hasil tersebut bahwa dinding rumah yang baik menggunakan tembok, akan tetapi dinding rumah responden tidak semua bangunan terbuat dari semen ada yang terbuat dari papan, bambu dan juga bata hal ini dapat menjadikan debu yang berasal dari dinding menyebabkan angin malam langsung masuk kedalam rumah. Jenis dinding yang mempengaruhi terjadinya ISPA disebabkan karena dinding yang yang sulit dibersihkan dan menjadikan penumpukan debu pada dinding, sehingga dinding akan dijadikan sebagai media yang baik bagi berkembangbiaknya kuman. Dinding yang lembap memungkinkan tikus dan kecoa membawa bakteri dan virus yang semuanya dapat berperan dalam memicu terjadinya penyakit pernafasan dan dapat berkembang biak dalam rumah.

3. Pola hubungan antara jumlah permasalahan lantai dengan kejadian ISPA

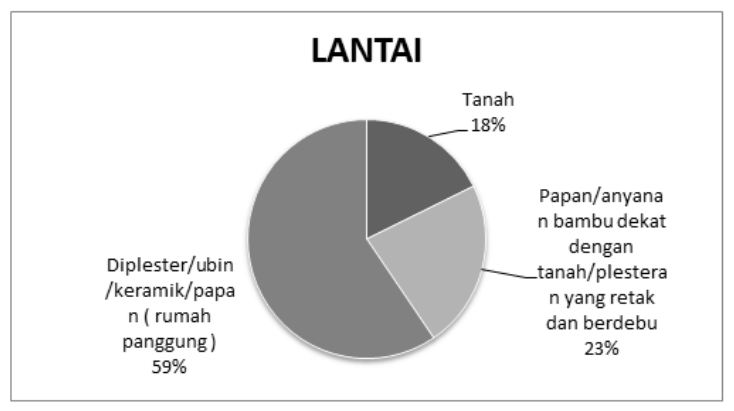

Gambar 3. Pola hubungan antara jumlah permasalahan lantai dengan kejadian ISPA

Berdasarkan hasil inspeksi sanitasi rumah sehat tahun 2019 menunjukan ada hubungan yang antara sanitasi lantai dengan kejadian ISPA di wilayah kerja Puskesmas Dukun bahwasanya Lantai yang baik harus kedap air, tidak lembap, bahan lantai mudah dibersihkan dan dalam keadaan kering dan tidak menghasilkan debu.

4. Pola hubungan antara jumlah permasalahan jendela kamar tidur dengan kejadian ISPA

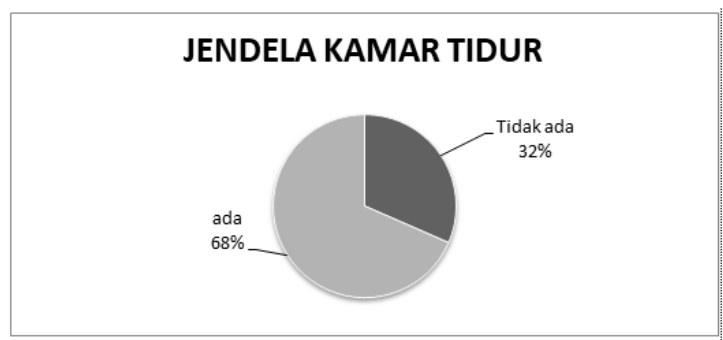

Gambar 4. Pola hubungan antara jumlah permasalahan jendela kamar tidur dengan kejadian ISPA

Berdasarkan hasil tersebut bahwa jendela kamar tidur yang tidak baik atau tidak ada dapat menimbulkan gangguan pada penghuni rumah khususnya ISPA. Karena sirkulasi masuknya udara kerumah tidak terjadi dengan baik sehingga undara 
sulit masuk dan rumah akan menjadi lembap.

5. Pola hubungan antara jemlah permasalahan jendela ruang keluarga dengan kejadian ISPA

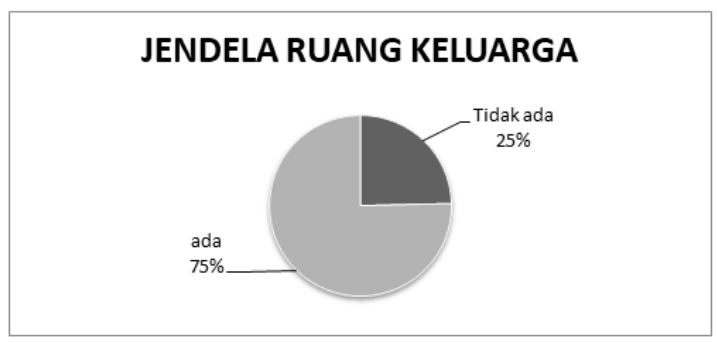

Gambar 5. Pola hubungan antara jumlah permasalahan jendela ruang keluarga dengan kejadian ISPA

Berdasarkan hasil tersebut bahwa pengaruh jendela ruang keluarga tidak jauh berbeda dengan jendela kamar tidur yaitu jika tidak ada sirkulasi udara maka keadaan rumah akan menjadi lembap dapat meningkatkan pertumbuhan kuman dan bakteri pathogen penyebab ISPA di udara

\section{Pola hubungan antara jumlah permasalaahan ventilasi dengan kejadian ISPA}

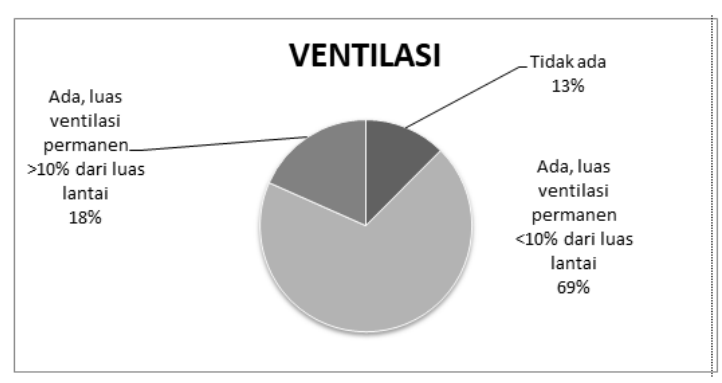

Gambar 6. Pola hubungan antara jumlah permasalaahan ventilasi dengan kejadian ISPA

Berdasarkan hasil tersebut bahwa sebagian rumah responden memiliki ventilasi yang kurang baik, dimana responden sering tidak membuka jendela, sebagian rumah responden juga memiliki lubang ventilasi yang dibuat kurang dari $10 \%$ luas lantai dari luas ruangan sehingga sirkulasi udara terjadi lebih sedikit.

7. Pola hubungan antara jumlah permasalahan lubang asap dapur dengan kejadian ISPA

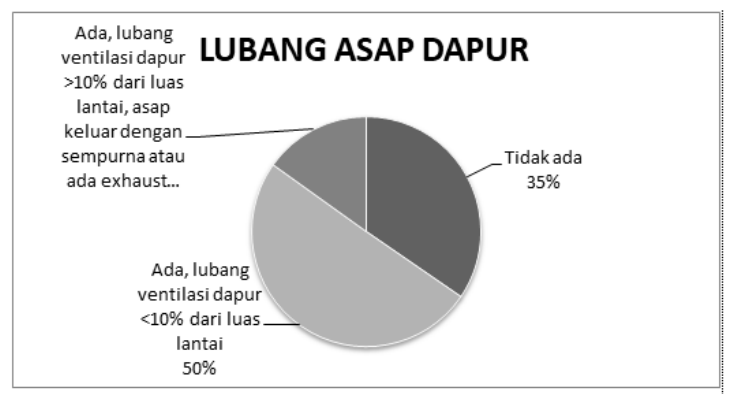

Gambar 7. Pola hubungan antara jumlah permasalahan lubang asap dapur dengan kejadian ISPA

Berdasarkan hasil tersebut bahwa sebagian rumah responden memiliki lubang asap dapur. Tetapi sebagian pada saat memasak tidak membuka lubang asap dapur sehingga asap dapur tersebut tidak bisa keluar dan mengendap didalam rumah akibatnya penghuni rumah hanya menghirup asap dapur tanpa ada udara dari luar masuk kedalam rumah.

8. Pola hubungan antara jumlah permasalahan pencahayaan dengan kejadian ISPA 


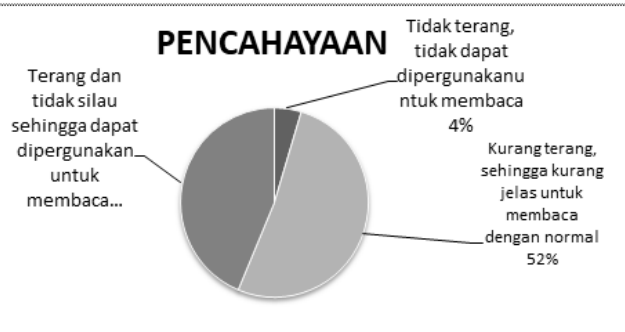

Gambar 8. Pola hubungan antara jumlah permasalahan pencahayaan dengan kejadian ISPA

Berdasarkan hasil tersebut bahwa pada pencahayaan rumah warga sebagian kurang terang terutama pada pagi hari yang kurang mendapatkan cahaya alami, hal ini disebabkan karena jendela kurang luas dan jarang dibuka pada siang hari, tidak memiliki ventilasi rumah dan sebagian ada rumah yang menghadap kebarat dan utara. Cahaya matahari penting karena selain dapat membunuh bakteri-bakteri patogen di dalam rumah juga mengurangi kelembapan ruangan dalam rumah.

9. Pola hubungan antara perilaku penghuni dengan jumlah permasalahan membuka jendela kamar tidur

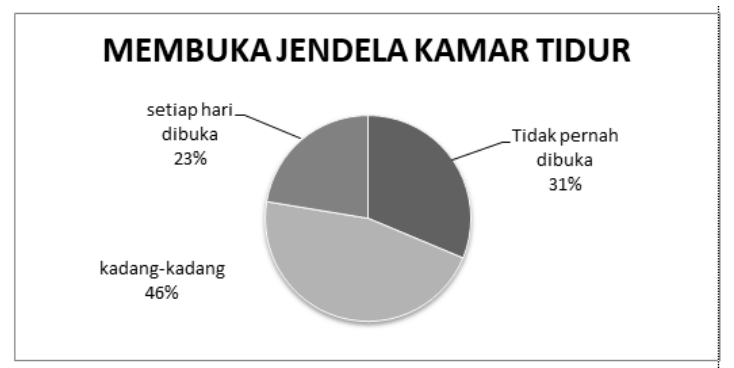

Gambar 9. Pola hubungan antara perilaku penghuni dengan jumlah permasalahan membuka jendela kamar tidur
Dalam gambar yang sebelumnya yaitu sanitasi jendela kamar tidur yang kurang baik dikarenakan fasilitas sanitasi yang kurang. Berdasarkan perilaku penghuni untuk membuka jendela kamar tidur dalam setiap harinya hanya $23 \%$ warga yang jendela kamar tidurnya dibuka. Selebihnya warga kurang membuka bahkan ada yang tidak pernah. Dalam hal tersebut bisa dikatakan bahwa, pertama mereka tidak mengerti dampak dari tidak membuka jendela kamar tidur, kedua faktor kemalasan, dan yang ke tiga yaitu faktor kebiasaan warga.

10. Pola hubungan perilaku penghuni dengan jumlah permasalahan membuka jendela ruang keluarga

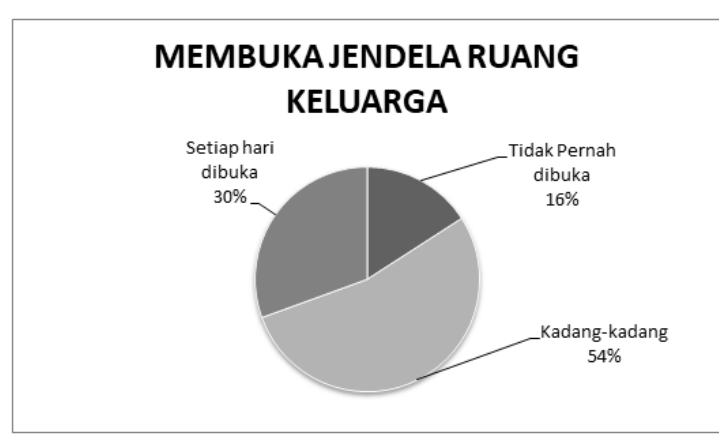

Gambar 10. Pola hubungan perilaku penghuni dengan jumlah permasalahan membuka jendela ruang keluarga.

Dalam gambar yang sebelumnya yaitu sanitasi jendela ruang keluarga yang luasnya kurang dari $10 \%$ luas lantai dikarenakan kuranya biaya dan warga merasa cukup dengan ukuran jendela tersebut. Berdasarkan perilaku penghuni 
untuk membuka jendela ruang keluarga berjumlah $30 \%$ tidak jauh berbeda dengan perilaku penghuni untuk membuka jendela kamar tidur dalam setiap harinya hanya yaitu $23 \%$ warga yang jendela ruang keluarga setiap harinya dibuka. Selebihnya warga kurang membuka bahkan ada yang tidak pernah. Dalam hal tersebut bisa dikatakan bahwa, warga sering berpergian dan hanya sebagai penghias atau hanya mengandalkan pintu sebagai tempat keluar masuknya udara.

\section{PEMBAHASAN}

Dalam pengimplementasian inspeksi penilaian sanitasi dasar rumah yang pertama mulai dari persiapan mengetahui sasaran survey, kedua pelaksanaan yaitu dengan menentukan jumlah sampel, waktu dalam pelaksanaan yang dilakukan oleh tenaga sanitarian. Ketiga melakukan pengolahan data dan analisis data oleh petugas sanitasi dengan melakukan tabulasi data hasil pengumpulan di lapangan. Hasil tabulasi dari masingmasing wilayah kerja puskesmas kecamatan dilaporkan ke Dinas Kesehatan kabupaten untuk dianalisa berdasarkan kriteria penilaian sehingga didapatkan gambaran kondisi rumah di tingkat kabupaten. Terakhir rekomendasi dan tindak lanjut, pihak puskesmas memberikan informasi kepada camat atau sektor terkait yang berkepentingan tentang persentase keluarga yang menepati rumah sehat sebagai masukan tentang gambaran faktor resiko untuk intervensi lebih lanjut sebagai upaya penyehatan perumahan di wilayahnya. Dalam upaya penyehatan perumahan di wilayah rumah tersebut maka pihak puskesmas melakukan monitoring dan evaluasi yang berupa kunjungan dan sosialisasi. Berdasarkan hasil inspeksi sanitasi rumah sehat tahun 2019 jumlah permasalahan dari setiap komponben sanitasi dasar rumah yang mempengaruhi penyakit ISPA dapat disajikan dalam table 4.1 dibawah ini;

Tabel 1. Tabel hasil Inspeksi Sanitasi

Dasar Rumah

\begin{tabular}{|c|c|c|c|}
\hline No & Komponen & & Jumlah \\
\hline \multirow{3}{*}{1} & \multirow{3}{*}{$\begin{array}{l}\text { Langit- } \\
\text { langit }\end{array}$} & Tidak ada & 222 \\
\hline & & $\begin{array}{l}\text { Ada, bersih } \\
\text { dan tidak } \\
\text { rawan } \\
\text { kecelakaan }\end{array}$ & 56 \\
\hline & & $\begin{array}{l}\text { Ada, kotor, } \\
\text { sulit } \\
\text { dibersihkan } \\
\text { dan rawan } \\
\text { kecelakaan }\end{array}$ & 46 \\
\hline \multirow[t]{3}{*}{2} & \multirow[t]{3}{*}{ Dinding } & $\begin{array}{l}\text { Bukan } \\
\text { tembok ( } \\
\text { terbuat dari } \\
\text { anyaman } \\
\text { bambu/ilalan } \\
\text { g ) }\end{array}$ & 89 \\
\hline & & $\begin{array}{l}\text { Semi } \\
\text { permanen, } \\
\text { atau batu } \\
\text { yang tidak } \\
\text { diplester/pap } \\
\text { an yang } \\
\text { tidak kedap } \\
\text { air }\end{array}$ & 129 \\
\hline & & $\begin{array}{l}\text { Permanen ( } \\
\text { tembok/pasa } \\
\text { ngan bata } \\
\text { yang }\end{array}$ & 112 \\
\hline
\end{tabular}




\begin{tabular}{|c|c|c|c|}
\hline & & $\begin{array}{l}\text { diplester/pap } \\
\text { an yang } \\
\text { kedap air ) }\end{array}$ & \\
\hline \multirow[t]{3}{*}{3} & \multirow[t]{3}{*}{ Lantai } & Tanah & 58 \\
\hline & & $\begin{array}{l}\text { Papan/anyan } \\
\text { an bambu } \\
\text { dekat } \\
\text { dengan } \\
\text { tanah/plester } \\
\text { an yang } \\
\text { retak dan } \\
\text { berdebu }\end{array}$ & 75 \\
\hline & & $\begin{array}{l}\text { Diplester/ubi } \\
\text { n/keramik/pa } \\
\text { pan ( rumah } \\
\text { panggung ) }\end{array}$ & 195 \\
\hline \multirow[t]{2}{*}{4} & \multirow{2}{*}{$\begin{array}{l}\text { Jendela } \\
\text { kamar tidur }\end{array}$} & Tidak ada & 100 \\
\hline & & ada & 217 \\
\hline \multirow[t]{2}{*}{5} & \multirow{2}{*}{$\begin{array}{l}\text { Jendela } \\
\text { ruang } \\
\text { keluarga }\end{array}$} & Tidak ada & 66 \\
\hline & & ada & 202 \\
\hline \multirow[t]{3}{*}{6} & \multirow[t]{3}{*}{ Ventilasi } & Tidak ada & 38 \\
\hline & & $\begin{array}{l}\text { Ada, luas } \\
\text { ventilasi } \\
\text { permanen } \\
<10 \% \text { dari } \\
\text { luas lantai }\end{array}$ & 211 \\
\hline & & $\begin{array}{l}\text { Ada, luas } \\
\text { ventilasi } \\
\text { permanen } \\
>10 \% \text { dari } \\
\text { luas lantai }\end{array}$ & 56 \\
\hline \multirow[t]{3}{*}{7} & $\begin{array}{l}\text { Lubang } \\
\text { asap dapur }\end{array}$ & Tidak ada & 112 \\
\hline & & $\begin{array}{l}\text { Ada, lubang } \\
\text { ventilasi } \\
\text { dapur <10\% } \\
\text { dari luas } \\
\text { lantai }\end{array}$ & 163 \\
\hline & & $\begin{array}{l}\text { Ada, lubang } \\
\text { ventilasi } \\
\text { dapur >10\% } \\
\text { dari luas } \\
\text { lantai, asap } \\
\text { keluar } \\
\text { dengan } \\
\text { sempurna } \\
\text { atau ada } \\
\text { exhaust fan } \\
\text { atau sejenis }\end{array}$ & 49 \\
\hline \multirow[t]{2}{*}{8} & \multirow[t]{2}{*}{$\begin{array}{l}\text { Pencahayaa } \\
\text { n }\end{array}$} & $\begin{array}{l}\text { Tidak } \\
\text { terang, tidak } \\
\text { dapat } \\
\text { dipergunaka } \\
\text { nuntuk } \\
\text { membaca }\end{array}$ & 15 \\
\hline & & $\begin{array}{l}\text { Kurang } \\
\text { terang, } \\
\text { sehingga } \\
\text { kurang jelas }\end{array}$ & 169 \\
\hline
\end{tabular}

\begin{tabular}{|c|c|c|c|}
\hline & & $\begin{array}{l}\text { untuk } \\
\text { membaca } \\
\text { dengan } \\
\text { normal }\end{array}$ & \\
\hline & & $\begin{array}{l}\text { Terang dan } \\
\text { tidak silau } \\
\text { sehingga } \\
\text { dapat } \\
\text { dipergunaka } \\
\text { n untuk } \\
\text { membaca } \\
\text { dengan } \\
\text { normal }\end{array}$ & 143 \\
\hline 9 & $\begin{array}{l}\text { Membuka } \\
\text { jendela } \\
\text { kamar tidur }\end{array}$ & $\begin{array}{l}\text { Tidak } \\
\text { pernah } \\
\text { dibuka }\end{array}$ & 102 \\
\hline & & $\begin{array}{l}\text { kadang- } \\
\text { kadang }\end{array}$ & 151 \\
\hline & & $\begin{array}{l}\text { Setiap hari } \\
\text { dibuka }\end{array}$ & 73 \\
\hline 10 & $\begin{array}{l}\text { Membuka } \\
\text { jendela } \\
\text { ruang }\end{array}$ & $\begin{array}{l}\text { Tidak } \\
\text { pernah } \\
\text { dibuka }\end{array}$ & 51 \\
\hline & keluarga & $\begin{array}{l}\text { kadang- } \\
\text { kadang }\end{array}$ & 172 \\
\hline & & $\begin{array}{l}\text { Setiap hari } \\
\text { dibuka }\end{array}$ & 98 \\
\hline
\end{tabular}

Berikut adalah bagan dari implementasi monitoring dan evaluasi berupa sosialisasi.

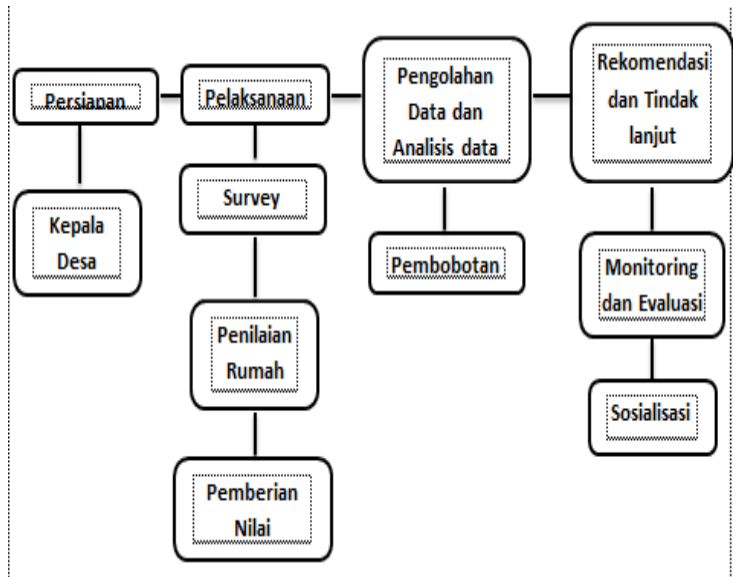

Gambar 12. Implementasi Sanitasi Dasar Rumah Monitoring dan Evaluasi

Dalam

pengimplementasian monitoring dan evaluasi berupa sosialisasi di mulai dari tahap persiapan, mulai dari 
menentukan sasaran lokasi yang dituju, menentukan judul permasalahan yang di alami masyarakat/desa serta waktu pelaksanaan sosialisasi. Selanjutnya pelaksanaan mencari narasumber yang ahli dalam bidang permasalahan tersebut kemudian menyampaikan materi dan yang terakhir adalah diskusi.

Dari hasil praktek kerja lapangan di UPT Puskesmas Dukun bahwa rumah yang ada di wilayah kerja Puskesmas Dukun terdapat langit-lnagit yang tidak rawan kecelakaan ada $14 \%$, ada tetapi sulit dibersihkan ada $17 \%$ tetapi rumah yang tidak ada langit-langitnya ada 69\%. Dinding rumah permanen kedap air ada $34 \%$, dari anyaman bambo $27 \%$ dan semi permanen ada 39\%. Lantai rumah dari tanah terdapat $8 \%$, berbentuk kramik $59 \%$, dan yang terbuat dari papan 23\%. Sedangkan yang mempunyai jendela tidur sebanyak $69 \%$ dan yang tidak mempunyai jendela kamar tidur 32\%. Dibanding jendela kamar tidur lebih banyak yang mempunyai jendela ruang keluarga sebanyak $75 \%$ dan yang tidak mempunyai jendela ruang keluarga sebanyak $25 \%$. Ventilasi yang $<10 \%$ dari luas lantai ada $69 \%$, sedangkan $>10 \%$ dari luas lantai terdapat $18 \%$ dan yang tidak punya ventilasi ada $13 \%$. Sedang kan yang tidak memiliki lubang asap dapur 35\%. Lubang asap dapur yang $<10 \%$ dari luas lantai ada $50 \%$ sedangkan $>10 \%$ dari luas lantai terdapat $15 \%$. Sedangkan komponen yang meliputi pencahayaan rumah yang ada di wilayah kerja Puskesmas Dukun sudah memiliki intensitas cahaya yang masuk meliputi terang dan tidak silau sebanyak $44 \%$ dan yang kurang terang sebanyak $52 \%$ dan yang tidak terang ada $4 \%$. Sedangkan dilihat dari perilaku penghini masyarakat di wilayah kerja puskesmas dukun yang setiap hari membuka jendela kamar tidur sebanyak 23\%, yang kadangkadang membuka $46 \%$ dan yang tidak pernah membuka sebanyak $31 \%$ rumah. Tidak hanya jendela kamar tidur masyarakat juga memiliki jendela ruang keluarga yang setiap hari membuka sebanyak 30\%, yang jarang membuka ada $54 \%$ dan yang tidak pernah membuka jendela ruang keluarga sebanyak $16 \%$.

Dengan demikian terdapat hubungan antara sanitasi dasar rumah dengan kejadian ISPA di wilayah kerja Puskesmas Dukun yang di pengaruhi oleh Sanitasi rumah dan kesadaran warga.

\section{KESIMPULAN}

Berdasarkan pengolahan data dari hasil dan pembahasan diatas maka dapat disimpulkan bahwa:

1. Kondisi sanitasi dasar rumah warga yang ada di wilayah kerja Puskesmas Dukun Kabupaten Gresik adalah 270 rumah meliputi $30 \%$ yang memenuhi 
syarat dan $70 \%$ yang belum memenuhi syarat.

2. Hubungan sanitasi dasar rumah dengan kejadian ISPA di wilayah kerja puskesmas Dukun Kabupaten Gresik dipengaruhi oleh sanitasi dasar rumah seperti; ventilasi yang kurang baik,pencahayaan kurang, jendela kamar tidur dan ruang keluarga yang jarang dibuka, kondisi lantai yang berdebu, langit-langit yang mudah menimbulkan debu dan sulit untuk dibersihkah, dinding rumah yang lembap dan faktor perilaku penghuni hal tersebut dapat mempengaruhi karena jika ventilasi maupun jendela tidak dibuka maka sirkulasi udara tidak dapat berjalan dengan baik dan akan mengakibatkan kelembapan yang menimbbulkan patogen yang menyebabkan ISPA.

\section{DAFTAR PUSTAKA}

Jumawal, April. 21 Juli 2013. Higiene Sanitasi, Perencanaan Tingkat Puskesmas Program Kesling. Diakses di https://arpiljumawal. blogspot.com2013/07/perencanaantingkat puskesmas-program.html

Notoatmodjo, S., 2003a. Ilmu Kesehatan Masyarakat . Jakarta: Rineka Cipta.(http:// eprints. ums.ac.id/596 5/1/J410050018.PDF)

Republik Indonesia. 2014 . Peraturan Menteri Kesehatan. Tentang Pusat Kesehatan Masyarakat. Diakses di http://www.depkes.go.id/resources/ download/peraturan /PMK-No-75Th-2014-ttg-Puskesmas.pdf 